
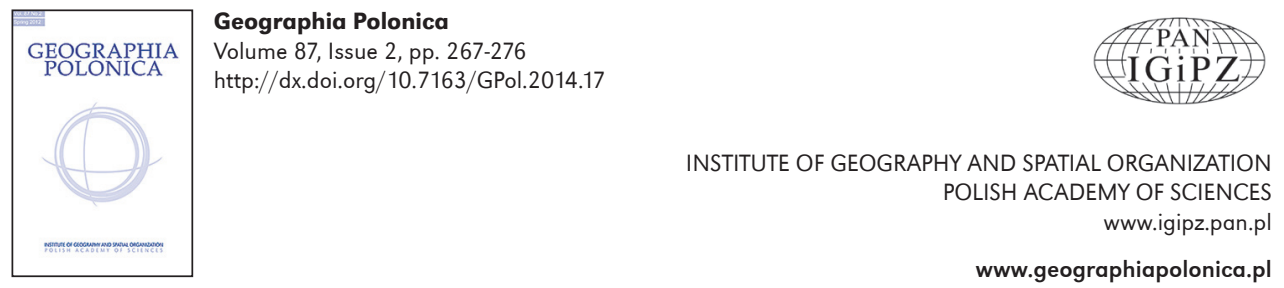

www.geographiapolonica.pl

\title{
CHANGES, CHALLENGES AND RESPONSIBILITIES IN GEOGRAPHICAL EDUCATION: THE INTERNATIONAL GEOGRAPHY OLYMPIAD
}

\author{
Lex Chalmers ${ }^{1}$ - Kathryn Berg ${ }^{2}$ \\ Co-chairs of the IGU Olympiad Task Force \\ ${ }^{1}$ University of Waikato \\ Geography, Tourism \& Environmental Planning \\ 3210, Hamilton: New Zealand \\ e-mail: lex@waikato.ac.nz \\ ${ }^{2}$ Royal Geographical Society of Queensland \\ 237 Milton Rd, Milton 4064 Queensland: Australia \\ e-mail: admin@rgsq.org.au
}

\begin{abstract}
Geography has never been so accessible; new media present documentaries about diverse places, supported by travelogues that ask intriguing questions, with superb imagery of natural and cultural features, all supported by emerging digital cartographies. These geographies reach many more people than the well-cited texts of 19th century geographers such as Humboldt and Ritter, yet the paradox is that contemporary Geography is not identified as a critical part of the educational entitlement of young people. The essay explores this paradox with reference to the changes in education in the last 150 years and a commentary on the scholars and institutional frameworks that share responsibility for the current and future status of the discipline. Since 1996 the International Geographical Union (IGU) has accepted a key challenge faced by Geography; the process of fostering the regeneration of the discipline by engaging young people. The IGU has supported ten International Geography Olympiads since 1996, with the eleventh Olympiad scheduled for Krakow in 2014. The essay outlines the nature of the Olympiad where field trips and cultural activities provide an unparalleled experience for young scholars exhibiting international excellence in Geography. These young people are our future.
\end{abstract}

\section{Key words}

young geographers - geographical education - International Geography Olympiad • Krakow • International Geographical Union - International Year of Global Understanding 


\section{Introduction}

In the Introduction to The Source Book of the Polish Classical Geography (Wilczyński 2012) there is an assessment of the history of thinking and practice that has shaped geography as a discipline. While the arguments are supported mostly with reference to Polish material, we argue that many features of the Polish experience are common to Geography. The historiography of the subject provides a launching pad for the evaluation of the Olympiad as an option for renewing Geography; by understanding the origins of our discipline and focusing on the recent patterns of change, we understand better the challenges faced by the Olympiad and the responsibilities of the IGU's Olympiad Task Force. In assessing the changes in Geography that promote the Olympiad, we focus on the fundamental changes in Geography in Europe during the 19th and 20th century as a baseline in the first section of the essay. The almost-universal 'geography of the local' in early school education is noted, but the changes in the patterns of the geography offered in secondary education are more important. Secondary geography provides the platform for the Olympiad.

The institutional changes in education and applied research in Geography have increasing defined roles and responsibilities for particular groups or 'agencies' in geographical education. Generally, however, 'governments' have the widest responsibility for education because of its economic, social and cultural impacts; education is important, the focus of the second United Nations Millennium Goal ${ }^{1}$ for the 21 st Century. Centres of academic scholarship are responsible for generating and disseminating new theories and methods in geography, and professional bodies in geography develop pedagogic skills

\footnotetext{
1 The second of the UN's Millennium Development Goals (United Nations 2000) formalises the importance of universal education by identifying the target (2a) of ensuring that, by 2015, children everywhere, boys and girls alike, will be able to complete a full course of primary schooling.
}

to teach content, analytical and thinking skills in Geography teachers. Professional societies, like the IGU, also have important roles to play, with the Olympiad always associated with the established IGU Commission on Geographical Education². The second substantial section of the essay reviews the agencies like the IGU Olympiad Task Force that have responsibility for promoting Geography to a new cohort of geographers every year. We make the case for the IGU as a responsible body, with an interest in young geographers and a commitment to the international Olympiad as a bridging device for those interested in using Geography in their careers.

The final section of the essay deals with one of the most important challenges the discipline faces; understanding change and accepting the responsibility of designing and implementing pathways for young people in Geography. The pathways start in the primary and secondary education sectors, where understanding local and national geographies remain an important focus of teaching and learning. But the geographies we encounter in the 21st century are global, as both the Brundtland Report (1987) and the proposed 2016 UN International Year of Global Understanding ${ }^{3}$ (UNIYGU) recognise. Young geographers benefit from stepping beyond their national communities, engaging in inter-cultural experiences and committing to the academic and professional development opportunities that the IGU Olympiad provides. In the essay we describe a number of pathways available to young people, and we focus on the Olympiad in particular. Within the broadening range of contacts in the international community, the Olympiad model provides bridges between cannon subjects (such as Chemistry, Physics, Mathematics, Biology, Geography and Informatics) in the secondary sector and further education or professional development in post-secondary institutions.

\footnotetext{
2 The IGU Commission on Geographical Education is arguably the longest standing of all current Commissions.

3 The IGU is the key sponsor of this initiative; see http://www.global-understanding.info/what-is-iygu/.
} 
Anczewska and Charzyńska (2012: 6) document the role of Olympiads in this transition in Poland.

\section{Change and Geography}

With reference to the analysis of the disciplinary changes in Geography, we take the 'long view' of developments. The roots of classical geography, particularly the contributions of Graeco-Roman, Arabic and Chinese scholars between $600 \mathrm{BC}$ and $600 \mathrm{AD}$, are often acknowledged (Wrigley 1965), but the early modern period of European scholarship is the focus of more attention. The history of the European universities is often traced to those established between 1088 and 1160 (Perkin 2006), but the growth in the number of tertiary institutions is more rapid in the 18th and 19th centuries (Frijhoff 1996); the Jagiellonian University, the oldest university in Poland, was established in 1364. The tertiary sector, emerging in the 19th century provided a widening platform for the identification of excellence in tertiary Science and the Arts.

Underpinning the recorded history of the tertiary sector is the more important development of compulsory education systems at the national level; importance is assessed on the basis of the number of persons learning their own geographies, and the demographic point ${ }^{4}$ at which this learning is generally undertaken. Progressing from often-cloistered learning centres of the early Middle Ages $^{5}$, education became an area of responsibility within the emerging nation state, with the role of geography explicated through the strategic importance of cartography (Branch 2011). Andrzej Frycz Modrzewski (1551) first proposed compulsory education in Poland, but this was not implemented until 1825 (in the Prussian areas of Poland) and 1873

\footnotetext{
${ }^{4}$ The contemporary view is that education is a whole-of-life engagement, and the term 'compulsory education' is often used to indicate learning undertaken at a constituted school on a regular basis by young people between the ages of 5 and 15 .

5 The European 'Middle Ages' are generally held to be between AD 500 and AD 1500 (Holmes 2000).
}

(in the Austrian areas). Compulsory education provided the structures within which both interest and excellence in particular disciplines could be identified.

In the 19th century Geography became recognized as a discrete academic discipline and also became part of a typical university curriculum in Europe. It would be easy to link the awareness of geography to the rise of the "Modern World System" as described by Wallerstein in publications between 1974 and 1989 (e.g. Wallerstein 1989). Wallerstein argues that the mercantile and military capacities of Europe led to a changing awareness of global geography, to which the great exploration-based writing of geographers such as von Humboldt (1859) and Ritter (1849) contributed. A location-based focus dominated University Geography teaching for a century, without reference to the earlier advocacy of scholars such as Varenius for the role of science in physical geography (Buache 1752). Swissborn Arnold Guyot re-inforced the idea that regional geographies need to move beyond 'mere description', to explain and generalise the nature of geographical features (Guyot 1850). The development of geographical societies supported the intellectual endeavour of the universities, with the Société de Géographie (France) established in 1821, the Royal Geographical Society in Britain in 1830, and the Russian Geographical Society in 1845. In 1851 the American Geographical Society was established and the Polish Geographical Society (Polskie Towarzystwo Geograficzne) came into being in 1918 (the year Poland regained independence after over a century of partition). The twentieth Century saw the creation of national scholarship awards for tertiary studies in Geography (sometimes explicitly on the basis of national Olympiads) with international awards in the last 30 years as the 'global' nature of issues affecting our collective future became apparent.

It is useful to take the UNESCO (1951) international review of curriculums in History, Geography and Social Studies as a benchmark against which to assess the changes 
in geographical education in the last 60 years. In primary geography, the UNESCO document shows that the focus on the local area/ state is almost universal in early education, but only a few national systems place importance on the use of maps or cartography. The secondary Geography curriculums in the re-building era after the international conflicts of 1939-45 also have a strong emphasis on the geographies of the domestic state, often within a regional (e.g. Asia, Latin America and Europe) setting. Regional studies dominate over systematic studies, with population and economics evident in human geography prescriptions, climate, vegetation and landforms dominate in physical geography. With reference to an international Olympiad, the 1951 curriculums seem 'terminal' in that there are no obvious links to tertiary education. There are few direct references to global issues or international relations, and an Olympiad event in this educational climate would have been problematic.

Changes in the secondary curriculum are generally internally driven, and there are only a few international curriculums. From its roots in a UNESCO Handbook in Switzerland in 1948, the International Baccalaureate Organisation (IBO) established (in 1968) a Geography Diploma Programme (IBO 2014) that integrates physical and human geography, with the aim of providing both scientific and socio-economic methodologies. The Diploma programme reaches beyond national interests: it examines key global issues, such as poverty, sustainability and climate change. It considers examples and detailed case studies at a variety of scales, from local to regional, national and international. The IBO website notes that 2,464 schools in 142 countries are authorized to teach the Diploma Programme currently. In Poland, 35 schools offer the IBO Diploma programme, with comparative figures for Germany (54), Australia (63), Brazil (20) and Canada (152). The Cambridge

6 Poland is one of the few exceptions, with the explicit reference to the "Introduction to the reading and making of maps and plans" (UNESCO 1951: 74).
International Examinations (2014), or CIE, are the second international examinations worth comment. In contrast to the global issues of the IBO curriculum, the 2014 CIE Core Geography ${ }^{7}$, Advanced Physical Geography and Advanced Human Geography are much more traditional. However significant these changes may seem in the internationalisation of (geographical) education, the opportunities provided by the IGU Olympiad remain a prime tool in promoting the discipline.

There is value in looking at the International Baccalaureate and Cambridge programme for several reasons; they have significant pickup in state schools in many countries. Both programmes focus on providing certification of "preparedness to enter tertiary (Geography) studies" but they also attract critical comment on the basis of their costs, their elitist nature and the failure to incorporate local geographies. The structure and formats of the programmes are useful for the evaluation of the IGU Olympiad, and the challenges to establish an appropriate format for the Olympiad are dealt with explicitly in the third substantive section of the essay.

The vocational drivers and selection options in tertiary education make the terminal point of compulsory education the ideal time for an event like the IGU Olympiad to operate. As the third section of this essay demonstrates, a 16-19 age group qualification allows for variable timing of terminal points for national systems, and the IGU Olympiad stipulation that students must be 'pre-tertiary' equalises the variability in national systems. What the Olympiad offers is simultaneously constrained and compelling. It is constrained by offering an opportunity for only four young people from each member country of the IGU. It is compelling because it offers shared living and interaction for young people with a common passion; they compete seriously, but the evidence suggests they share and interact in a very positive way. As winners of national entrance,

\footnotetext{
7 See the specifications at http://www.cie.org.uk/ images/93285-2014-syllabus.pdf.
} 
they also have improved access to their desired programme of tertiary study.

Olympiad students face their own series of changes when they seek to use their secondary education in tertiary environments. The Bologna Process ${ }^{8}$ is a major effort to establish equivalency in tertiary education that began with a series of agreements between European countries; it was designed to ensure comparability in the standards and quality of higher education qualifications. The Bologna Accords of 1999 do not require common curriculums, nor do they require geography-based programmes to respond in the same way to major changes in our discipline. The 'quantitative revolution' (Burton 1963), the 'cultural turn in geography' (Jackson 1989), the emergence of spatial technologies and the importance of global geographies are approached in different ways in different institutions in different countries. The IGU Olympiad is well-placed to benchmark achievement, both personal and national, before a significant point of change in the geographies offered to young people.

\section{Responsibilities}

Responsibility for sustaining geographical education and the Olympiad does not lie with one set of government or professional agencies, nor academic societies or corporate bodies. It lies rather with a combination of these organisations, and also with individuals who understand the importance of environments and cultures at a variety of scales, and who recognise the importance of thinking and communicating about these places to others, often with the aid of cartography. In terms of renewing or reproducing Geography, there is a need to recognise new thinking and new understanding of the discipline. A number of remarkable debates have shown that these responsibilities are taken seriously (Harvey 1973: 120-127), and they often engage young scholars prepared to rethink the current conventions. The

\footnotetext{
${ }^{8}$ A description of the Bologna Accords are found at http://en.wikipedia.org/wiki/Bologna_Process.
}

Olympiad is one of a few international testinggrounds and/or forums for an initial engagement with post-secondary geography.

The Olympiad movement has caught the attention of national governments, and the consequence is often a modest commitment of state funding in programmes that identify excellence, and which are generally run by non-governmental organisations. In many countries the status of selection in a national team is high, even though committing to an Olympiad may mean team members have to engage in some funding raising. The non-government organisations that accept responsibility to support Olympiad participation of national teams are generally professionally based and often closely related to secondary teaching. The dividends for national governments come in the form of generally sound to excellent performances of almost all participating teams, and the recognition through individual medals awarded to the very best students. In general, the students selected to represent the more than 30 teams that compete at the IGU's International Geography Olympiad are excellent ambassadors of their country.

The original International Geography Olympiad ${ }^{9}$ was organised in the Netherlands in 1996 for five teams (Ankoné 1996a). Task Force status within the IGU required acceptance of a number of responsibilities for some complex tasks. Statutes were established and Standard Operating Procedures (SOPs) were put in place leading to the official formation of the Olympiad Task Force in 2004. Members of the Task Force are the chair and the organisers of the past, the present and the future Olympiads. The Task Force may co-opt up to three additional International Board members. The chair of the Task Force is nominated by the International Board with this

\footnotetext{
9 The first IGU contest was named the International Geography Competition because (from 1993 to 2001) the US National Geographic Society used the name International Geography Olympiad for its competition for younger student (now the National Geographic World Championship). The IGU contest was re-named International Geography Olympiad in 2006 and we use that name throughout this essay.
} 
Board consisting of one adult representative of each country participating in the present or previous Olympiad.

Both the IGU Commission of Geographical Education and the IGU Olympiad Task Force participate in IGU meetings and attract some support for operating expenses. Since 2008, the IGU has also been committed to getting funding support for the Olympiad Task Force from the Local Organising Committee responsible for the Congress or Regional Conference. The support is welcome, but more resources are always required to meet professional servicing and the cost of running SOPs. Academic and professional commitments cover some of the short fall, but we need to make a case to corporate entities we work with about assisting the Olympiad. In the past, the publisher Westermann and the Environmental Sciences Research Institute (ESRI) have supported the Olympiad.

With reference to the Olympiad, there are a set of complex relationships that define the patterns of responsibility. Since the Brundtland Report (1987), global education ${ }^{10}$ around issues such as sustainable futures has been much more explicitly on the international agenda. Secondary education and the increasing call for (I) comparative assessment of performance using international curriculums (like the IBO and CIE) and (II) international assessment (PISA and TIMSS ${ }^{11}$ ) leads to global questions about who/which group can do more to take young geographers into both tertiary study and professional activities that draw on their skills in Geography. On the basis of 10 successful events, and drawing on IGU's experience of more than a century of representing geography, the Task Force is well-placed to promote geography and global understanding.

\footnotetext{
10 The Brundtland Report (1987) states that "The radical change in human attitudes foreseen by acceptance of the concept of sustainable development depends upon a vast campaign of public education and re-education, a worldwide debate around these life-anddeath issues."

11 See the Trends in International Mathematics and Sciences Study at http://nces.ed.gov/timss/index.asp.
}

\section{Challenges}

For the most able students the senior secondary school provides opportunities to demonstrate excellence and rare talent in Geography. The creation of national 'Olympiads', bringing together the best students in the country, has been a feature of some countries for many decades. In Poland, for example Professor Anna Dylikowa (supported by the Main Board of the Polish Geographical Society) requested the Minister of Education to establish the Geography Olympiad Committee in 1974. The Minister acceded and funded the Olympiad. Internationally, however, Olympiads involving a wide range of countries, were first proposed in the 1950s in a range of science subjects. Science skills were perhaps easier to test and validate than those in subjects with language dependence, like geography. Mathematics claims international seniority, with the first Olympiad held in Romania (http://en.wikipedia.org/wiki/ Romania) in 1959. More than 100 countries now compete, with the Olympiad seen as the pinnacle of mathematical competition by secondary students. Other subjects developed international Olympiads in approximately the following order; Physics (1967), Chemistry (1968), Informatics (1989), Biology (1990), Philosophy (1993), Geography (1996), Junior Science (2004), Astronomy (2007) and Earth Science (2007).

The development of the International Geography Olympiad can be traced to the 1994 IGU Regional Conference in Prague, where geography educators from Poland and the Netherlands launched the idea of an International Geography Olympiad, discussing it with colleagues in the IGU Commission on Geographical Education. The first Olympiad was held in conjunction with the 1996 IGU Congress in The Hague, well supported by the Royal Dutch Geographical Society and the Institute for Curriculum Development at Enschede (Ankoné 1996b). From 1996 to 2012 Olympiads were held biennially, with all but two in close association 
with an IGU Congress or Regional Conference. This strength of the link with its International Union is not shared by any of the other student Olympiads. The connection is valued by the Geography Olympiad community as both enhancing the status of our Olympiad, and as signalling that the world's foremost international body of geographers recognises and encourages our youngest geographers.

The first Olympiad attracted teams from five countries. By the 2013 Olympiad in Kyoto this number had grown to 32. Only three countries have participated in all ten Olympiads - the Netherlands, Poland and Slovenia. In the early Olympiads participation was largely European, particularly Eastern European. The Task Force has made efforts to widen the geographic spread of participating countries and this has been successful, particularly in Asia. Unfortunately, no South American country has ever entered the Olympiad and only three African countries have participated. In 2013, teams came from the following regions: nineteen from Europe, eight from Asia, two from Oceania, two from the Americas and one from Africa. The number of teams participating is expected to increase at the Krakow Olympiad, with efforts made to reach new national communities.

Between 2012 and 2016 the Olympiad schedule is annual, matching the schedule of IGU Regional Conferences. After 2016 the IGU will revert to its previous pattern of holding only one regional conference between the four-yearly Congresses. It is intended that the International Geography Olympiad will remain an annual event, in line with the practice of other student Olympiads and the annual pattern of national Olympiads. Finding hosts for the years in which there is no congress or regional conference will be a challenge. This situation occurred in 2004 when the United Kingdom decided not to organise an International Geography Olympiad in conjunction with the IGU Congress in Glasgow. Poland accepted the challenge, hosting the International Geography Olympiad in Gdynia. With the 2014
Olympiad in Krakow, Poland will become the only country to have hosted two Olympiads. The 2014 Olympiad is being organised by the Polish Geographical Society and the Pedagogical University of Krakow. The Krakow Olympiad has an effective Local Organising Committee. As well as the logistical organisation of the Olympiad, the Local Organising Committee is asked to source funds from government, associations and corporations to support the participation fees paid by teams.

Because curriculums in Geography vary between countries, the three tests that make up the Olympiad have to be international; it is a challenge to ensure fairness for students who have been educated in different systems. The guidelines for the three tests of the Olympiad are described on the Task Force website (International Geographical Union 2013). The Written Response Test (WRT) and the MultiMedia Test (MMT), are developed collegially by members of the International Board; all participating countries are asked to submit draft resources and questions. The WRT and MMT committees are appointed by the Task Force; these two committees then select the content of the two tests. Because local knowledge is essential, the Local Organising Committee is largely responsible for the Field-work Test (FWT), and they collaborate with an international committee appointed by the Olympiad Task Force. In all test preparations extended negotiation takes place. The marking of student papers is done by international panels using assessment guidelines and marking schedules prepared by Task Force members in association with a test sub-committee. The marking is done in pairs or small teams, and this provides valuable professional learning for geography teachers' unfamiliar with certain types of questions. Developing tests from international submissions is useful, and the materials provided in the Task Force website provide some models of good practice in geographical education. In our experience, some students (and for that matter some geography educators) are not accustomed to the very open-ended questions included in the Olympiad in order to properly test the 
students' ability to analyse and synthesize information and draw conclusions.

The International Geography Olympiad is now well established, and for that Geography owes a debt to the challenges faced by the first co-chairs of the IGU Task Force (Joop van der Schee and Henk Ankoné), to the various local committee and to the IGU Executive who have generally been very supportive of the Olympiad as a point of engagement for young geographers. We also acknowledge the support of the IGU Commission on Geographical Education and their journal International Research in Geographical and Environmental Education (IRGEE). IRGEE carried an influential series of national reviews of contributing Olympiad programmes (Garcia-Garcia 2007; Liiber \& Roosaare 2007; Naumov 2007; Winter \& Berg 2007, Schee \& Kolkman 2010).

\section{Conclusion}

The UNESCO (1951) review of international secondary curriculums provides a platform for us to view the impact of changes in our discipline, and to assess the challenges of engaging young people in Geography. The national secondary curriculums of sixty years ago were designed as a terminal education point, they were highly variable with a strong local and national focus, and only rarely looked at global issues. Universities were largely autonomous, and the demand for a cohort of (Geography) graduates to contribute to national and international development was in the future. Since 1951 there has been an increasing demand for 'planners', economic managers and (technology-based spatial) analysts in a series of changes (Burton 1963; Harvey 1973) that have encouraged school geographers to look for tertiary qualifications.
The International Geography Olympiad sits in this liminal space. Awareness of global issues, as represented by the UN-sponsored Brundtland Report (1987) and proposed International Year of Global Understanding (2013), has helped to change the focus from the local and national to the global. An international Geography 'Olympiad' would have been highly problematic 60 years ago, but the case for such a collaboration, cultural exchange and competition has become much more compelling in the last two decades. At one level the International Geography Olympiad provides often the first mediated, inter-cultural experience for young people, at another it recognises excellence in our discipline, and participation/success in the Olympiad is a useful form of credentialing in tertiary sector admissions.

The International Geographical Union has supported the Olympiad since the foundational efforts of geographers in the Netherlands and Poland. The Task Force website (IGU 2013) provides the most accessible record of activities and constitutional organisation. The site has the details of the upcoming Olympiad in Krakow in August 2014. The Krakow Olympiad Local Organising Committee (2014) site contains an account of the establishment of Polish national Olympiads in 1974 and the invitation to the Krakow event. The program promises a full range of social and cultural activities alongside field trips and formal tests. We anticipate that the event will have wide appeal, with full cultural engagement and outstanding performance in the various tests from our top scholars. The opening meeting of the IGU Regional Conference (at Krakow on 18 August, 2014) will see some very talented young people - the winners of Olympiad Gold Medals - on the international stage for the first time. 


\section{References}

Anczewska M., Charzyńska K., 2012. Educational assessment of pupils in Poland. SA-eDUC Journal, vol. 9, no. 1, pp. 1-9.

Ankoné H., 1996a. The 1996 iGeo - The Hague, The Netherlands. http://www.geoolympiad.org/ fass/geoolympiad/1996/ [16 January 2014].

AnKONÉ H., 1996b. The 1st International Geography Competition. Royal Dutch Geographical Society, in four parts: General information and Quiz, 24 pp.; Written test and marking model, 18 pp.; Written test: Resource material, 18 pp.; Fieldwork assignment, $20 \mathrm{pp}$.

BRANCH J., 2011. Mapping the sovereign state: Technology, authority, and systemic change. International Organization, vol. 65, no. 1, pp. 1-36.

BRUNDTLAND G.H., 1987. Report of the World Commission on environment and development: Our common future. United Nations.

Buache P., 1752. Essai de géographie physique [in:] Memoires de l'Academie Royale des Sciences. Paris: De I'Imprimerie de Du Pont, pp. 399-416.

BURTON I., 1963. The quantitative revolution and theoretical geography. The Canadian Geographer / Le Géographe Canadien, vol. 7, no. 4, pp. 151-162.

Cambridge International Examination, 2014. Homepage. http://www.cie.org.uk/ [6 January 2014].

Krakow Olympiad local Organising Committee, 2014. iGeo Kraków 2014. http://www.olimpiadageograficzna.edu.pl/igeo2014/ [20 January 2014].

FrIJHOFF W., 1996. Patterns [in:] H. RidderSymoens (ed.), A history of the university in Europe. Vol. 2. Universities in Early Modern Europe (1500-1800). Cambridge: Cambridge University Press, pp. 43-106.

GarCIA-GARCIA F., 2007. The Geography Olympiad in Mexico. International Research in Geographical and Environmental Education, vol. 16, no. 3, pp. 271-279.

Guyot A., Felton C.C. (transl.), 1850. The earth and man: Lectures on comparative physical geography in relation to the history of mankind. New York: Scribner.

HARVEY D., 1973. Revolutionary and counter-revolutionary theory in geography and the problem of ghetto formation [in:] D. Harvey, Social justice and the city. London: Edward Arnold.

Holmes G., (ed.), 2000. The Oxford illustrated history of medieval England. Oxford: Oxford University Press.

IBO, 2014. Geography. International BACCALAUREATE ORganisation, https://www.ibo.org/ diploma/curriculum/group3/geography.cfm [6 January 2014].

IGU, 2013. The International Geography Olympiad (iGeo). International Geographical Union, http:// www.geoolympiad.org/ [20 December 2013].

International Year Of Global Understanding, 2013. Friedrich Schiller University Jena. http:// www.global-understanding.info/ [20 December 2013].

JACKSON P., 1989. Maps of meaning: An introduction to cultural geography. London: Routledge.

Liber U., RoosaAre J., 2007. Geography Olympiads in Estonia. International Research in Geographical and Environmental Education, vol. 16, no. 3, pp. 293-298.

Marsden W.E., 1980. The West German geography curriculum project: A comparative view. Journal of Curriculum Studies, vol. 12, no. 1, pp. 13-27.

ModrzewSKI A.F., 1551. Commentariorum De Republica emendanda libri quinque. Kraków: Drukarnia Łazarzowa.

Naumov A., 2007. The all-Russian geography olympiad. International Research in Geographical and Environmental Education, vol. 16, no. 3, pp. 283-292.

Perkin H., 2006. History of universities [in:] J.J.F. Forest, P.G. Altbach (eds.), International Handbook of Higher Education. 18, pp. 159-205

RitTer C., 1849. Die Erdkunde Asien, Kleinasien, Arabien. Berlin: Reimer.

UNESCO, 1951. A comparative study of curricula in history, geography and social studies. Paris: United Nations Educational, Scientific and Cultural Organisation.

United Nations, 2000. Millennium development goals and beyond. http://www.un.org/millenniumgoals/ [6 January 2014].

VAN DeR SCheE J., 2007. The International Geography Olympiad. International Research in Geographical and Environmental Education, vol. 16, no. 3, pp. 268-270. 
van der SChee J., Kolkman R., 2010. Multimedia tests and geographical education: The 2008 International Geography Olympiad. International Research in Geographical and Environmental Education, vol. 19, no. 4, pp. 283-293.

von Humboldt A., Otte E.C. (transl.) 1859. Cosmos: A sketch of a physical description of the universe. 5 vols, London: Henry G. Bohn.

WalleRSTEIN I., 1989. The Modern World-System III: The second era of great expansion of the capitalist world-economy, 1730-1840s. San Diego: Academic Press.

Westermann Schulbuch, 2010. Diercke International Atlas. (English edition), Braunschweig: Westermann Publishing.
WILCZYŃSKI W. (ed.), 2012. A source book of the Polish classical geography. Kraków: Wydawnictwo Księży Sercanów Dehon.

Winter K., Berg K., 2007. Fieldwork and the International Geography Olympiad. International Research in Geographical and Environmental Education, vol. 16, no. 3, pp. 299-306.

WRIGLEY E.A.,1965. Changes in the philosophy of geography [in:] R.J. Chorley, P. Haggett (eds.), Frontiers in geographical teaching. Methuen, London. pp. 3-24. 